\title{
2-Mesudiye ilçesi Merkez Camii haziresi mezar taşları yazıları
}

\section{Bekir SARIKAYA1}

APA: Sarıkaya, B. (2020). Mesudiye ilçesi Merkez Camii haziresi mezar taşları yazıları. RumeliDE Dil ve Edebiyat Araşturmaları Dergisi, (21), 23-38. DOI: 10.2900o/rumelide.835373.

\section{$\ddot{\mathbf{O} z}$}

Tarihe ışık tutan mühim vesika türlerinden biri de mezar taşlarıdır. Ölenin adının kalması için, hürmeten kendisine bir mekan verilir. Bu dar mekanda küçücük bir taş bu insanın geride kalanlarla iletişimini sağlar. Bu taş bazen fes başlıklı olur bir erkeğe işaret eder; gül bitki motifli olur bir hanıma işaret eder. Geride kalanlar, baş ucuna koydukları mezar taşına ölenin bazen sadece adını yazıp bırakırlar. Bazen de ölen kişi adına duygularını ve düşüncelerini nesirle veya şiirle yazarlar. Yazılanlar aslında ölüm karşısında yaşayakalanların kendi duygu ve düşünceleridir. Yazılarda mevta bir yandan Allah'tan af isterken, öte yandan insanlara öğüt verir, onlardan isteklerde bulunur, dua ister. Bazen bu istekler mevtanın taşına düşürülen tarih kıtalarıyla ifade edilir. İnsanlar ibret almak, sevdiklerini yad etmek vb. sebeplerle mezarlara gidip dua ederken mezar taşlarını da okurlar. Elinizdeki bu yazıda Mesudiye ilçesi (Ordu ili) Merkez cami haziresinde bulunan biri tarih düşürülmüş sekiz mezar taşı ele alınmıştır. Bu mezarların kimi başlıklı kimi başlıksız, fakat tamamı dikdörtgen şekillidir. Başlıksız olanların ikisi bitki kıvrımlı tepeli, biri üçgen tepeli, birinin ise tepesi kopuktur. Mezar taşlarında bulunan şiirler, şiirlerin yapısı, kelimeler, kelime grupları, tarihler, tarih belirtme kültürü ve özel isimler (ilçe adının taşlarda farklılaşması) tespit edilmiştir; böylelikle, cami haziresinde bulunan mezar taşları kültü de ortaya çıkarılmış olacaktır. Buradaki yazılar ile diğer cami mezarlıklarında yazılmış mezar taşları yazıları arasındaki bazı benzer ve farklı yönler ortaya konmuştur. Taşların yapı özellikleri konumuzun dışındadır. Amaç buradaki yazıları doğru okuyarak mezar taşları ile ilgili genel değerlendirmede bulunacaklara az da olsa örnek sunmaktır.

Anahtar kelimeler: Mesudiye cami haziresi, taş yazıları, kıtalar, tarih düşürme

\section{Mesudiye district Central Mosque burial ground tombstones inscriptions}

\begin{abstract}
One of the cornerstones of history are tombstones. A place is given to him in honor of the deceased to remember his name. In this narrow space, a narrow stone allows this person to communicate with the rest. This stone has a fez cap and belongs to a man or rose plant motif and belongs to a lady. Those who remain behind after the death of a person only write their name on the tombstone that the deceased put on the bedside. Sometimes they express their feelings and thoughts on behalf of the deceased in different prose or poetry. The rest actually tell their feelings and thoughts in the face of death. In the writings, the deceased asks God for forgiveness, on the other hand, he advises people and asks them to pray to him. Sometimes these wishes are expressed in historical verses with a chronogram on the deceased's tombstone. People go to the graves and pray for reasons such as taking lessons and remembering their loved ones, while they also read the tombstones. In the academic paper to be presented, eight tombstones, one of which has a chronogram, in the burial
\end{abstract}

1 Dr. Öğr. Üyesi, Afyon Kocatepe Üniversitesi, Fen Edebiyat Fakültesi, Türk Dili ve Edebiyatı Bölümü (Afyonkarahisar, Türkiye), bsarikaya@aku.edu.tr, ORCID ID: oooo-0002-9842-237X [Araştırma makalesi, Makale kayıt tarihi: 09.09.2020-kabul tarihi: 20.12.2020; DOI: 10.29000/rumelide.835373]

Adres

İstanbul Medeniyet Üniversitesi, Eğitim Bilimleri Fakültesi, Türkçe ve Sosyal Bilimler Eğitimi Bölümü, Türkce Eğitimi ABD Cevizli Kampüsü, Kartal-İstanbul/TÜRKIYYE e-posta: editor@rumelide.com
Address

İstanbul Medeniyet University, Faculty of Education Sciences,

Turkish and Social Scinces Education, Turkish Language Teaching

Education, Cevizli Campus, Kartal-İstanbul /TURKEY

e-mail: editor@rumelide.com 
ground of the Central mosque in Mesudiye district (Ordu province) will be discussed. Some of these graves are headed, some are headless, and all are rectangular. Two of the headless tombstones have a plant-folded top, one has a triangular top, and one has a broken top. The poems found on the tombstones, the structure of the poems, words, word groups, dates, the culture of indicating the date and special names (differentiation of the district name on the stones) will be determined, and the gravestone cult in the mosque's graveyard will be revealed. Some similar and different aspects between the inscriptions here and the gravestones inscriptions in other mosque cemeteries will be published. Structural characteristics of the stone is out of the question. Our aim is to present a few examples to those who will make a general evaluation about tombstones by reading the articles here correctly.

Keywords: Mesudiye mosque burial ground, stone inscriptions, verses, chronogram

\section{Giriş}

Tarihe ışık tutan mühim vesika türlerinden biri de mezar taşlarıdır. İnsan ölümünden sonra geride kalanlara ya güzel anılar bırakır, güzel anı bıraktıklarının ölümü ile birlikte güzel anılar da ölür. Ölen kişi ya güzel eserler bırakır. Güzel eserlerin okunmasıyla beraber kişinin güzelliği eserinin okunması bitene kadar devam eder. Bazen de ölümüyle birlikte bir mezar taşı kalır. Bu mezar taşı yok olana kadar gelen geçen onun adıyla beraber güzel sözü okur, hem ibret alır hem de kişiliği ile ilgili taştaki kadar bilgi öğrenir. O yazıyı da kendinden sonrakiler ya vasiyet edilen yazıyı ya da ölenin kişiliğine uygun kendi duygu düşüncelerini aktaran bir yazı olur. Bir güzel söz yazdırırlar. Bu sözlerin konusu ölüm karşısındaki duygu düşünceler, Allah’tan ve insanlardan istekler olur. Altına da unutulmaması için adı, sülalesi, ölüm tarihi vb. şeyler yazılır. Naaşına hürmeten kendisine verilen bu mekan kıyamet gününe kadar bu kişinin olur.

Sonra bu mezar taşlarını her bilim adamı kendi açısından inceler. Daha evvelden Mesudiye Kaleköyü mezar taşları 1993'te sanat tarihçileri tarafından incelenmişti. Mezar taşları ve yazılarıyla ilgili araştırmalarıyla tanınan Çal, makalesinde; "Türkiye'deki mezar taşlarının çok azı yayınlandı̆̆ için bu konudaki son durum henüz bilinmemektedir. Burada yayınlar itibarıyla bu konudaki genel durum belirlenmeye çalışılacaktır.” ifadesiyle mezar taşlarının tamamının araştırılarak ortaya konmadığını belirtmektedir. (Çal, 2015: 324). Yanık ve Kındığılı, birlikte Balıkesir ili Edremit ilçesi Narlı Köyü Camii haziresini konu alan bir çalışma ile kendi ifadeleriyle bu boşluğun doldurulması yönünde küçük de olsa bir katkı sağlama amaçlayan çalışma yapmışlardır. Zaman zaman mezar taşları üzerine böyle araştırmalar yapılmakta ve makaleler yazılmaktadır. Mesudiye merkez cami haziresinde bulunan bir mezar taşındaki tarih düşürmenin bulunduğu kıta daha önceleri dikkatimi çekmişti. Bu mezar taşlarını topluca inceleyip ortaya koyma gereğini hissederek bu çalışmalara ben de küçük bir katkıda bulunmayı düşündüm; mevcut olan taşların üzerinde bulunan yazıları tespit edip, edebi açıdan incelemeye ve üzerinde taşıdıkları değerleri ortaya çıkarmaya çalıştım.

\section{Mezar taşlarının şekil özellikleri}

Mezar taşları biçimlerine (yatay kesitlerine ve ön görünüsslerine) göre dikdörtgen, kare, yuvarlak ve çokgen olarak dört tipe ayrlırlar. (Çal, 2015: 306) Cami haziresinde bulunan taşların tamamı dikdörtgen şeklindedir. Ayrıca mezar taşları farklı başlıklar taşır. Bunlar başlıklarına göre genelde

Çoruhlu, Y., Çakır, Ö . (2011). Ordu'nun Mesudiye İlçesi / Kale Köyü'nden Bir Türkmen Kalesi, Mezar Taşları ve Üç Mezar Anit, Tarih Dergisi, o(36), 81-136. 
başlıklı ve başlıksız mezar taşları olmak üzere ikiye ayrılmıştır. (Çal, 2015: 306). Başlıklı taşlardan sadece üstü dar altı geniş bir fes çeşidi olan hamidî fes (Çal, 2015: 313) örneğinden 4 mezar taşı vardır. Başlıksız mezar taşlarının altı farklı şekli vardır: üçgen tepelikli, sivri kemerli, yuvarlak kemerli, palmet (bitki kıvrımlı bezeme) tepelikli, güneş tepelikli ve dilimli tepelikli (Çal, 2015: 307-308). Cami haziresinde ise üçgen tepelikli ve palmet (bitki kıvrımlı bezeme) tepelikli olmak üzere iki çeşidi görülür. Bir mezar taşının üst tarafı kırık olup, başlı̆̆ı veya tepeliği belli değildir.

Bu çalışmada önce mezar taşlarının resmini ve Latin harflerine çevirisi tabloda verilecek. Daha sonra yazı içinde bulunan kıtalar, ölen kişinin kimlik bilgileri ve ölüm tarihi vb. kısımlar hakkında açıklama yapilacaktır.

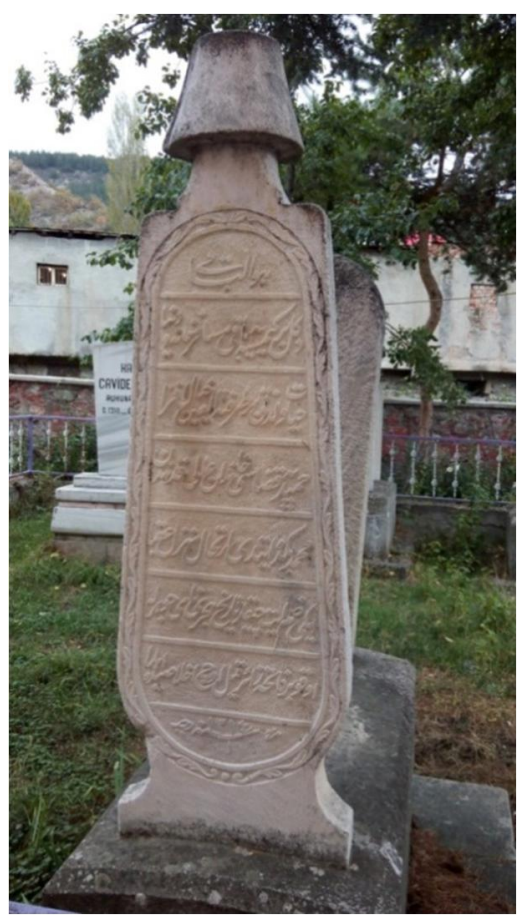

Hüve'l-Bāḳī

Degil bir kimseye bāḳī müsāfir-hāne dünyā

Ḥayāt u lezzzeti bir țarfetü’l-'ayn hayāāl-efzā

Ḥamīdiye Każāās hāanedān-1 'ālī ḳadrinden

Muḥammed Beg de étdi irtiḥāl-i menzil-i 'uḳbā

İki żamm ét çıḳar tārīĥ-i hicrī nāmı cevherle

Oḳu bir fâtiḥa zā'ir ḳıl üç iḩlāṣı da ihdā

Sene 1 Recep 1314

\section{Mezar taşı}

Şiir önce kurallı cümlelerle şöyle ifade edilebilir:

Ḥayāt u ležzeti bir țarfetü’l-‘ayn hayāl-efzā [olan] dünyā bir kimseye müsāfir-hnāne [olarak] bāḳī degil. // Ḥamīdiye Kạżāsı ḩānedān-ı ' ālī ḳadrinden Muhammed Beg de irtihāl-i menzil-i 'uḳbā étdi. // İki żamm ét // tārīh̆-i hicrī Nāmî cevherle çıkạ. // zā‘ir, bir fātiḥa oḳu, // üç ihlāṣı da ihdā ḳıl.

"Dünya hiç kimseye misafirhane olarak baki kalmaz. Dünya hayatı bir göz açıp kapayıncaya kadarlıktır, ve lezzeti hayal arttırandır. Hamidiye kazası yüce değerdeki köklü ailelerinden olan Muhammed Bey de ahiret yurduna irtihal etti."

Bu taşta bulunan şiirin ilk dörtlüğü hazırlık bölümüdür. Hazırlık mısralarında insan bir misafire, dünya ise misafirhaneye; hayat göz açıp kapamaya, lezzetler ise hayale teşbih edilmektedir. Şiirde aynı zamanda leffüneşir sanatı da yapılmıştır.

\footnotetext{
Adres | Address

İstanbul Medeniyet Üniversitesi, Ĕ̆itim Bilimleri Fakültesi, Türkçe ve Sosyal Bilimler Eğitimi Bölümü, Türkce Eğitimi ABD Cevizli Turkish and Social Scinces Education, Turkish Language Teaching Kampüsü, Kartal-İstanbul/TÜRKIYE $\quad$ Education, Cevizli Campus, Kartal-İstanbul /TURKEY e-posta: editor@rumelide.com $\mid$ e-mail: editor@rumelide.com
} 
Dünyada bir yere misafir olan insan misafirhaneye dinlenmek için uğrar, katedecek yolu vardır, daha uykuya dalmadan gitme vakti gelir, gözü yoldadır, hemen uyanır. Ne olduğunu anlayamadan, tam dinlenmeden yola koyulur, orayı terk eder. İnsan da dünyaya gelir, lezzete dalar, tam doyacakken ömür biter. Aynı zamanda burada ayete telmih vardır. ${ }^{3}$ Ecel gelip çattı̆̆ında insanın içine dünya hayatı bir göz açıp kapayıncaya kadar geçen bir süre içinde yaşanmış gibi bir his doğar. Şair, ölenin geçmiş hayatını onun gözüyle değerlendirerek mısralarında okuyanlara ders vermeye çalışır. Son iki mısrada şair, ölen adına sonradan kabrine gelip mezar taşını okuyanlardan bir Fatiha ve üç İhlas okuyarak dua etmelerini ister.

Şiirde edebi değer taşıyan beyit birinci beyittir. İkinci beyitte mevtanın adı mısralara karışmıs, beyitin aslî unsuru olmuştur. Kıta, kendisi için yazılan kişinin ölümü ile ilgili tarih düşülerek tamamlanmıştır. Bu taşta dikkat çeken unsur bu tarih düşürme sanatının icra edilmesidir. Bu sanatın nasıl yapıldığını anlamak için de tarih düşürme sanatını bilmek gerekir. İki beyitlik nazım biçimi kıt' $a$ olan şiirler genellikle xa xa şeklinde kafiyelenirler. Bazen de aa xa şeklinde kafiyelenerek kıt'a’nın bir türü olan nazım adını alırlar. xa xa xa ... şeklinde üç veya daha fazla beyit eklenirse kıt'a-i kebîre denilir. (Dilçin, 1983: 402) Burada, ölen kişinin adının içinde bulunduğu ve aa xa şeklindeki kafiyenin kullanıldığı nazım türünde bir şiir oluşturulmuştur. Daha sonra tarih beyti eklenerek türü, kıt'a-i kebîreye dönüştürülmüştür. Mezar taşında, tarih düşürme sanatı şiirin üçüncü beyitindedir. Birinci mısrada tarih düşürme ıstılahı, ikinci mısrada ise hesaplamanın yapıldı̆̆ı cümle yer alır:

İki żamm ét çıḳar tārị̆h-i hicrị nāmı cevherle

Oḳu bir fātiḥa zā‘ir ḳıl üç ihlāṣı da ihdā [ اوقو بر فاتحه زائر قيل اوز اخلاصيده اهدا ]

Tarih düşürme ıstılahı tarih çıkar, cevher ve zamm kelimeleridir. Tarih düşürme yapıldığı tarih çıkar ibaresinden anlaşllıyor. Misrada geçen cevher kelimesi beytin noktalı (mu'cem) harflerinin ebced4 değerlerinin hesaplanması gerektiğini gösterir (Karabey, 2015: 202). Metindeki zamm kelimesi de sayıların tam çıkmayacağını ve tarih düşürmede tamamlamalı (ta'miyeli) söylenenler kısmında değerlendirilerek ekleme yapılacă̆ını gösterir (Karabey, 2015: 126). Tarih aranırken söyleniş bakımından iki türlü değerlendirilir. Birincisinde tarih rakamla lafzen (bin üç yüz on dört gibi) söylenir. İkincisinde tarih rakamla açıç̧a söylenmeden harflerin ebced değeriyle bir diğer ifadeyle ma'nen söylenir. Tarih düşürme bu iki yoldan biri ile bulunur (Karabey, 2015: 61)

Bu bilgilere göre şiir; ma'nen, ta'miyeli ve mu'cem tarihe örnektir. Ölüm tarihinin hesabı, mu'cem tarih örneği olduğuna göre mısradaki noktalı harflerin ebced değerinin toplanıp, iki sayısının eklenmesiyle yapılmalıdır:

3 “Bir gün veya günün bir bölümü kadar kaldık; işte, saymakla görevli olanlara sor" derler. Mü’minûn, 23/113.

$4 \quad$ Harflerin ebced rakam değerleri

\begin{tabular}{|c|c|c|c|c|c|c|c|c|c|}
\hline 11 & 42 & 400 & 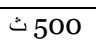 & ج 3 & 28 & $\dot{\tau} 600$ & 24 & ذ 700 & ر 200 \\
\hline j7 & 60 س & 300 ش & 90 & 800 ض & b 9 & 900 ط & $\varepsilon 70$ & $\dot{\varepsilon} 1000$ & 80 ن \\
\hline 100 ق & ك 20 & נ30 & 40 & ن 50 & 6 & .5 & 10 & & \\
\hline
\end{tabular}




\begin{tabular}{|c|c|c|c|c|c|}
\hline ق & 100 & ق & 100 & & \\
\hline ب & 2 & s & 10 & & \\
\hline ف & 80 & ج & 3 & & \\
\hline$ت$ & 400 & $\dot{\tau}$ & 600 & & \\
\hline j & 7 & ى & 10 & & \\
\hline \multicolumn{4}{|c|}{ Harflerin ebced toplamı: 1312} & Zamm 2: +2 & $=1314$ \\
\hline
\end{tabular}

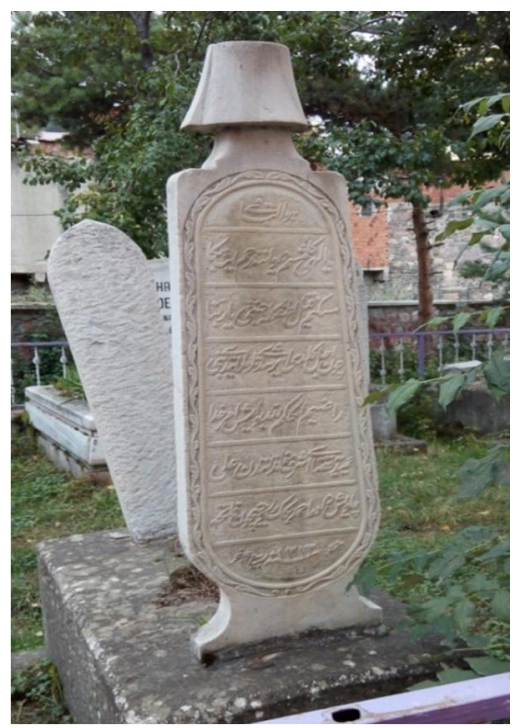

\section{Hüve'l-Bākīi}

Yā ilāhī, gelmişim dīvānına raḥm ét baya Miskinim ḳıl luṭfun-1la cenneti Yā rabbenā!

Çün ecel geldi érişdi tārumār étdi beni

Rāżīyım el-hü̈kmü li’llāh bu imiş emr-i Hudā

Ḥamīdiye ḳażāsı Eşref hānedānından ‘Alì

Çavış-zāde Aḥmed Begin rūḥı-y-çün fătiḥa

Sene 10 Rebī'u’l-āhir 1313

\section{Mezar taşı}

Hamidî fesli bu mezar taşında altı cümle bulunmaktadır:

Yā ilāhī, dỉvānına gelmişim, // baya raḥm ét. // Yā rabbenā! miskinim, // cenneti luṭfuy-ıla ḳıl. // Çün ecel geldi érişdi, beni tārumār étdi. // Rāżīỳm, // el-hükmü li’llāh, emr-i Ḩudā bu imiş.

"Ey Allah'ım, divanına geldim, bana rahmet et. Ya rabbi, miskinim, lutfunla cenneti nasip et. Ecel gelince beni mahvetti. Razıyım. El-hükmü lillâh. Hüda'nın emri buymuş.”

Şiirlerin ilk mısralarında bulunan hazırlık mısraları ters dönmüş gibidir. Son iki mısrada ecelin kendisini mahvettiğini, fakat Allah'ın emri karşısında razı olduğunu ifade eder. Bu mısralardan hareketle kişinin beklenmeyen bir ölümle karşılaştığı söylenebilir, kendisini tarumar edenin ecel olduğu, hayatından herhangi bir şikayetinin sözkonusu olmadığı görülmektedir. Şair asıl maksadını ilk iki mısrada ifade eder, Allah'ın divanına geldiğini, kendisine rahmet edilmesini ve cennete sokulmasını ister.

Şiir kısa cümlelerle tertip edilmiş, şiirde akıcı bir dil kullanılmıştır. Günlük konuşma diliyle yazılan şiir, içinde Arapça yapılar olsa da sadeliğini hissettirir. Şiir şekil itibarıly kıtadır. aa xa tarzında kafiyelenen kıtalara nazım denmektedir. (Dilçin, 1983: 202). Vezin olarak remel bahrinden fâ‘ilâtün/fâ‘ilâtün/fâ‘ilâtün/fâ‘ilün kalıbı kullanılmıştır. Bu mezar taşında şiirin vezni kusursuz görülmektedir. 


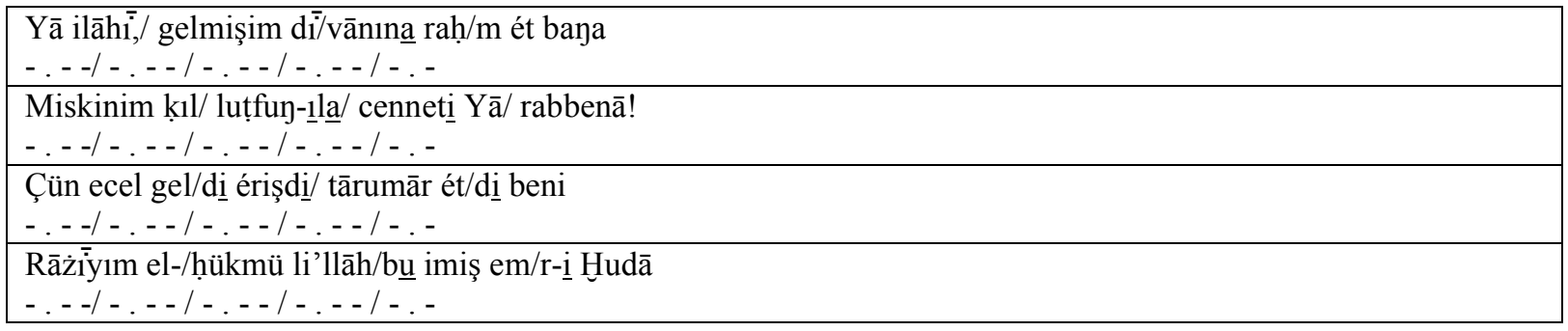

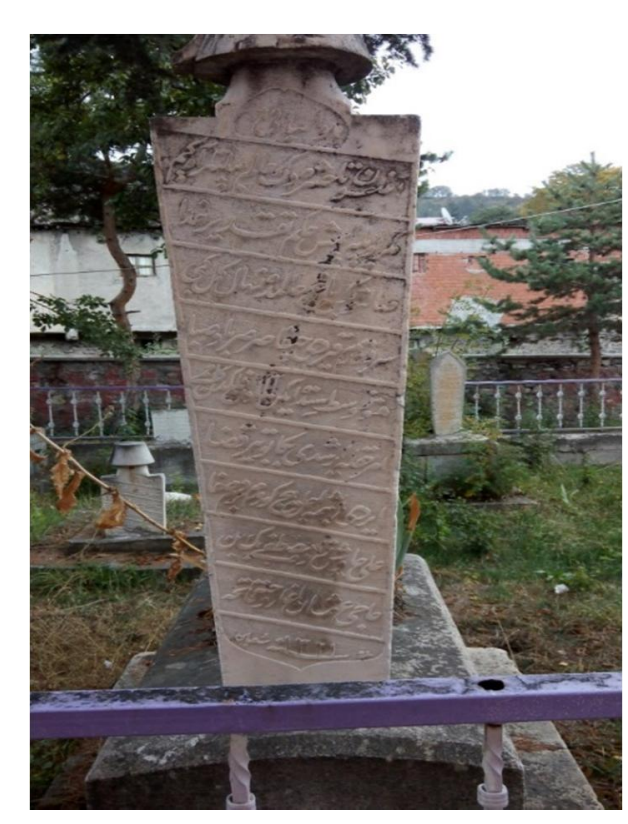

\section{Hüve'l-Bākīi}

Ag̉lasun tā ḥaşre dek ḥālim bilenler āh kim Meger böyle imiş ḥükm-i taḳdīi-i Ḩudā

Șalınurken bāg̀g-1 ‘ālemde nihāl-i gül gibi

Serv-i ḳaddim ḳırdı ḥayfã șarṣar-ı bād-ı șabā

Henūz vasaṭ-1 sinde iken almadan felekden kāmımı

Emr-i Ḥaḳḳ-1la érişdi baya bu tịr-i ḳażā

Érdi başıma ecel hiç görmedim bir dem șafā

'Alī Çavuş-zāde Muștafā Beg bin

Hācl 'OŚsmān Ag̉a rūḥuna fātiḥa

Sene Şa‘bān 1321

\section{Mezar taşı}

Mezar taşındaki şiiri şöyle kurallı cümleye çevirebiliriz:

Āh kim! hālim bilenler tā ḥaşre dek ag̉lasun. // Meger hüukm-i taḳdî̀-i Hudā böyle imiş. // Ḥayfā! Henūz vasaț-ı sinde iken felekden kāmımı almadan bāğ-ı 'ālemde nihāl-i gül gibi șalınurken, șarṣar-ı bād-ı șabā serv-i ḳaddim ḳırdı. // bana bu tî̄-i ḳażā emr-i Ḥaḳk-ıla érişdi. // Başıma ecel érdi. // Hịçbir dem ṣafā görmedim.

"Ah! hâlimi bilenler ta mahşere kadar ağlasın. Meğer ilahi hüküm buymuş. Hayfa! Henüz gençliğimin ortasındayken felekten kâmımı almadan dünya bahçesinde gül fidanı gibi gezerken kuvvetli bir rüzgar servi gibi boyumu kırdı. Bana Allah'ın emriyle kaza oku ulaştı. Başıma ecel ulaştı, hiçbir zaman safa görmedim."

Şiir uzun cümlelerle tertip edilmiş, akıcı ve anlaşılır bir dile sahiptir, bazı edebi sanatları da barındırır. Mezar, henüz babası hayatta iken eceli gelen bir delikanlıya aittir. Beklenmeyen bir ölümdür. Gençliğinin baharında kuvvetli bir hastalık nedeniyle vefat eden gencin herkes gibi birtakım emelleri vardır. O emellerine ulaşamadan, diğer insanlar gibi bazı dünyevi arzularını gerçekleştiremeden öbür aleme göç etmiştir. Bazı mezar taşlarında öleni tanıyanların ve hâlini bilenlerin anlayacağı fakat dışarıdan okuyanların anlayamayacağı bazı kapalı anlatımlar da bulunur. Bu durum mezar taşlarına yazılmak istenip de yazılamayan durumların bulunduğunu da gösterir. Şiirde divan edebiyatı 
mazmunları kullanılmıştır. Mısralarda teşbih-i belĭğler göze çarpar. Ayrıca mazmunlardan gül, ölen

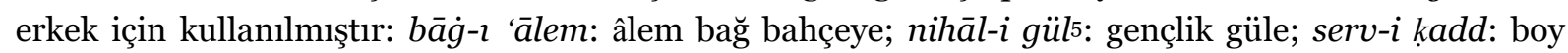

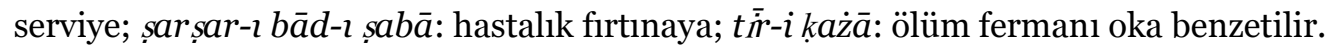

Kıt'aların xa xa şeklindeki kafiyelenişine, aynı kafiye türünden xa'lar eklenerek genişletilen kit'alara kıt’a-i kebîre denildiğini görmüştük. Burada üçüncü beyit eklenmiş, dördüncü beyite geçiş yapılmış fakat bir mısra eklenmiş, xa xa xa xa a şeklinde kafiyelenmiştir. Bazı mısralarda vezin olarak remel bahrinden fâ‘ilâtün/fâ‘ilâtün/fâ‘ilâtün/fâ‘ilün kalıbı tespit edilirken bazılarında vezin sorunlu olarak kalmıştır ${ }^{6}$ :

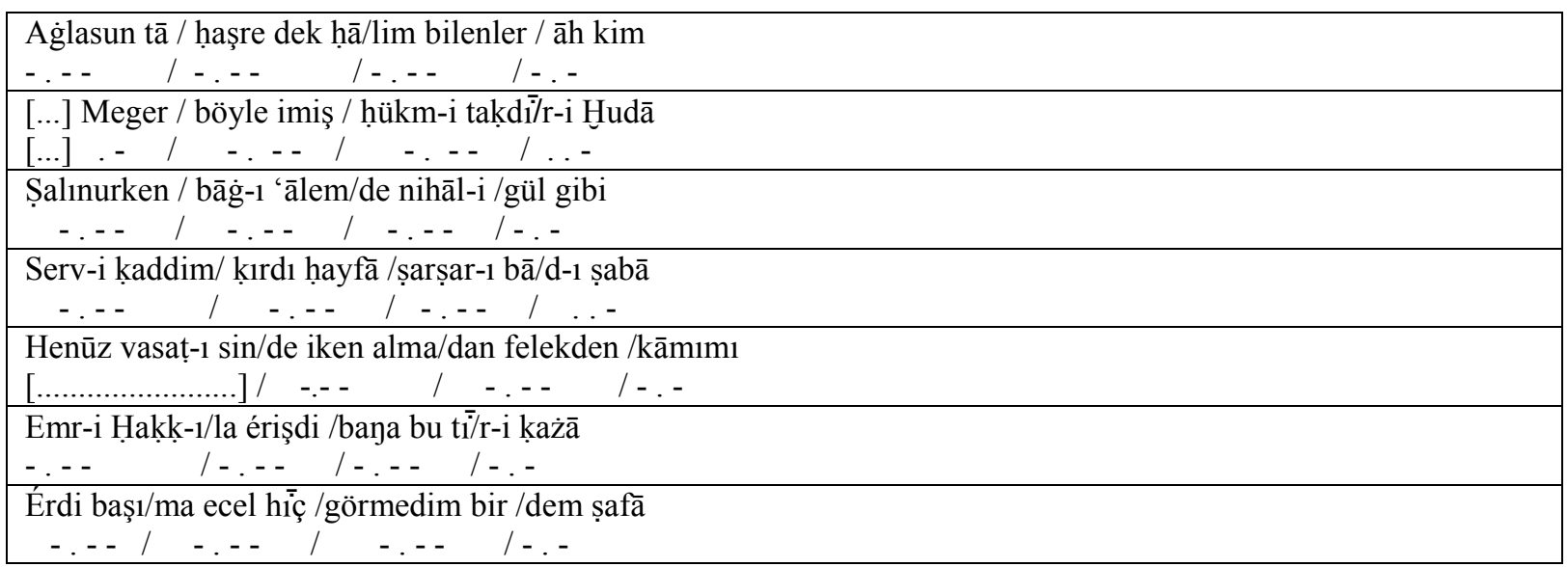
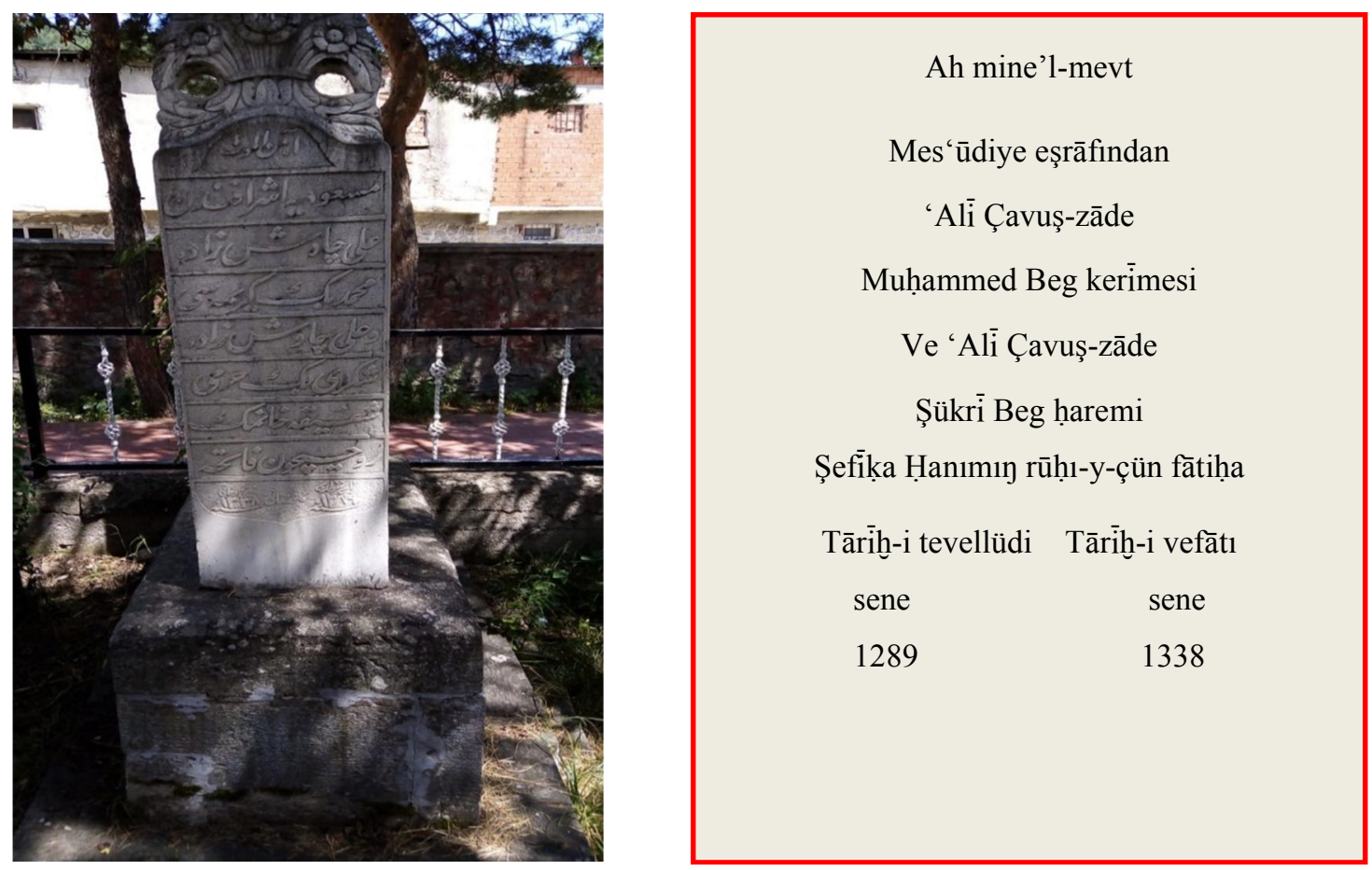

$5 \quad$ Yani her nerede 'gül' zikrettiler ise akabinde 'bülbül' getirdiler. Hangi mahalde ki nâle-i uşşâkı feryâd-ı bülbüle nisbetle zikretmeyi murad eylediler ise nihâl-i kamet-i mahbûbu güle teşbih ile vird-i mezâmîni destelediler" (Ali Cemâleddin, Arûz-ı Türkî, İstanbul 1291, s. 116-117'den alıntı; Akün, s. 422)

6 Bu kıta bir mısra eksiktir. Beşinci mısrada vezin tutmamaktadır. Sanki beşinci mısra ile yazılmayan yedinci mısra anlam bakımından uyumlu hâle getirilerek bir mısra ile yazılmıştır. Şu anda kesin bir bilgiye ulaşamıyoruz.

Adres

İstanbul Medeniyet Üniversitesi, Eğitim Bilimleri Fakültesi, Türkçe ve Sosyal Bilimler Eğitimi Bölümü, Türkçe Eğitimi ABD Cevizli Kampüsü, Kartal-İstanbul/TÜRKIYE e-posta: editor@rumelide.com
Address

İstanbul Medeniyet University, Faculty of Education Sciences,

Turkish and Social Scinces Education, Turkish Language Teaching

Education, Cevizli Campus, Kartal-İstanbul /TURKEY

e-mail: editor@rumelide.com 


\section{Mezar taşı}

Tepesi çeşitli bitki kıvrımları şeklinde bir tipe sahip olan mezar taşları daha çok kadınların baş ve ayak taşlarında kullanılır. (Çal, 2015: 308) Buradaki mezar taşı da palmet (bitki kıvrımlı/bitkisel) tepelikli olan olup görüntüsü hoştur. Herhangi bir duygu ve düşüncenin ifade edilmediği kitabede sadece ölen kadının babasının ve eşinin hangi sülaleden olduğu belirtilmiş, akabinde de ruhu için Fatiha okunması istenmiştir.

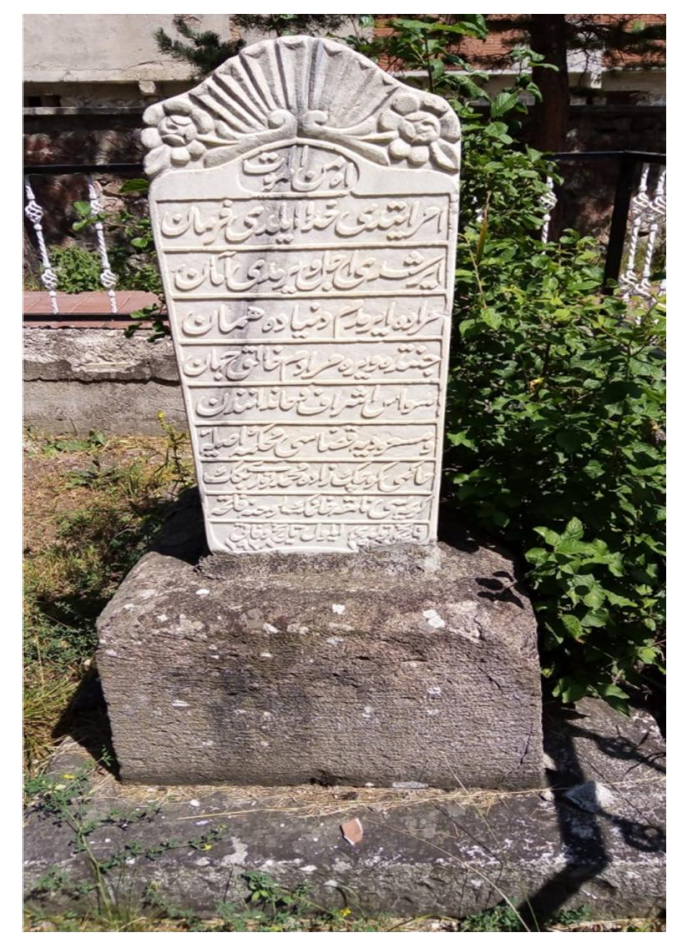

\begin{tabular}{|c|}
\hline Ah mine'l-mevt \\
\hline Emr étdi Huudā eyledi fermān \\
\hline Érişdi ecel vérmedi amān \\
\hline Murāda érmedim dünyāda hemān \\
\hline Cennetde vére murādım Ḩāliḳ-i cihān \\
\hline Sivās eşrāf ve ḥānedānından \\
\hline Ve Mes‘ūdiye ḳażāsı maḥkeme-i așliyye \\
\hline Hākimi Küçük-zāde Muḥammed Nūrī Begin \\
\hline Kerīmesi Nāmıḳa hanımın rūḥuna fātiḥa \\
\hline Tārihh-i tevellüdi Eylül Tārihh-i vefătı \\
\hline $192 \ldots$ \\
\hline
\end{tabular}

\section{Mezar taşı}

Bu mezar taşında klasik mezar taşı yazılarından biri yazılmıştır.7 Bitki tepelikli bu mezar taşı evvelki bitki tepelikli mezar taşındaki gibi Ah mine'l-mevt serzenişiyle başlar. İlk iki beyitte hazırlık mısraları bulunur. Ecelin Allah tarafından gönderildiğini ve canın alındığını ifadeden sonra duyguların açıklandığı son mısralarda kişinin ancak cennete girerek muradına ereceği belirtilir. Ölen kişinin kazaya Sivas'tan hakimlik mesleği gereği gelen Muhammed Nūri Bey'in kızı olduğunu ve her ölenin tek isteği ruhu için Fatihanın okunması olduğu gibi burada da istek aynıdır. Şekil bakımından bir Osmanlı mezar taşı özelliği taşıdığı hâlde yazı bakımından bu taşın en önemli özelliği; cumhuriyet dönemine ait olup miladi takvimin kullanıldığı tek taş olması, klasik mezar taşı yazıları örneklerinden birinin kullanılması ve bu kişinin başka yerden bu bölgeye gelmesidir.

\footnotetext{
7 Bu şiir, Seyyid Nizam cami haziresinde 106. numaralı mezar taşında biraz farklı şekliyle bulunmaktadır: (Berk, 2018: 292) Emretti Hüdâ eyledi fermân // Ayırdı ecel vermedi amân // Murâda ermedim dünyâda hemân // Cennette vere murâdım Hâlik-i Rahmân
} 


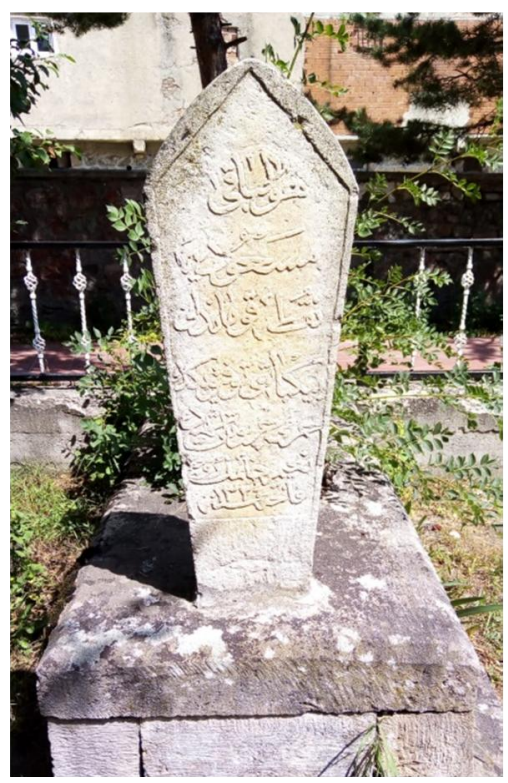

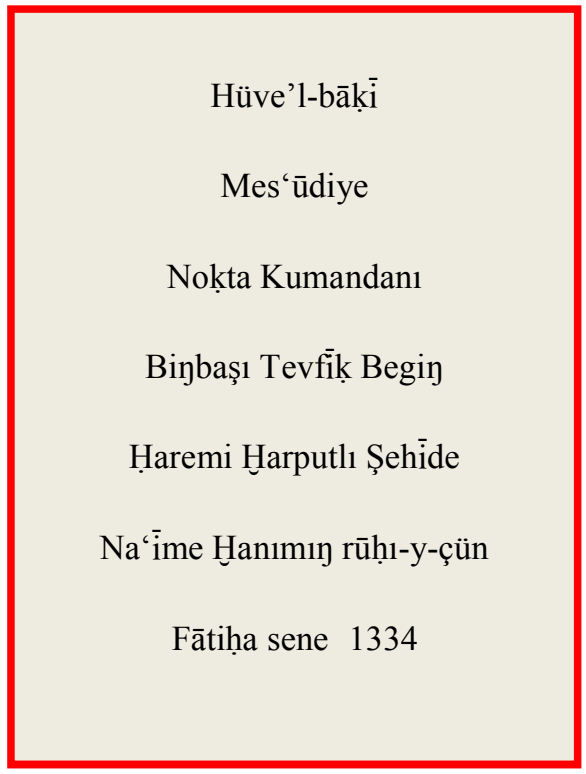

\section{Mezar taşı}

Üçgen tepelikli adı verilen bu tip mezar taşı, özellikle Ege bölgesinde baş taşlarında çok kullanılmasına karşılık Türkiye genelinde ayak taşlarında fazladır. (Çal, 2015: 307). Burada ise baş taşı olarak kullanılmıştır. Ölen kişinin eşinin karakol komutanlı̆̆ı mesleği yazıldıktan sonra memleketi Harput/Elazığ yazılmış ve Fatiha okunması istenmiştir.

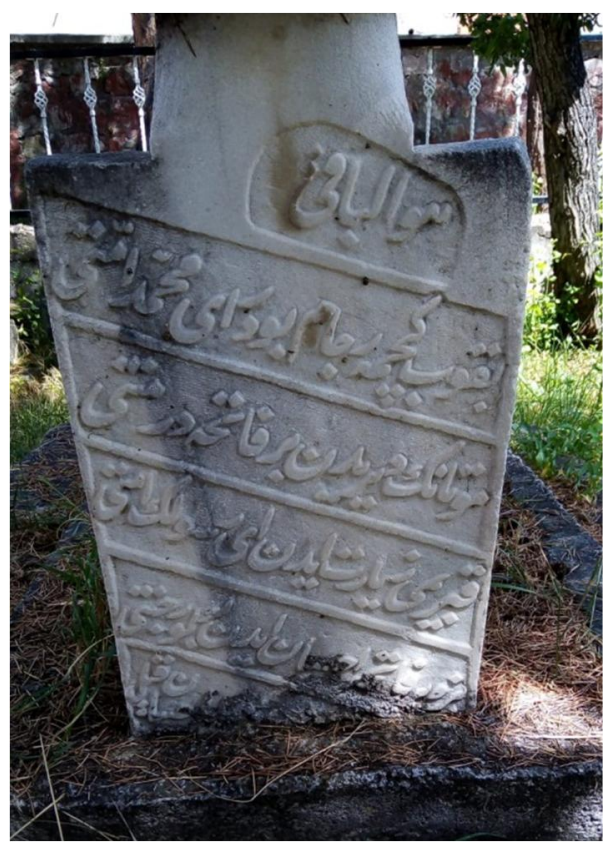

\section{Hüve'l-bākīi}

Baḳup geçme ricām budur Ey Muhammed ümmeti

Mevtānı̀ diriden bir fātihadır minneti

Kabrimi ziyāret éden Ey Resūlün ümmeti

Bize fātiḥa iḥsān éden bulur cenneti .ị̣sān ḳ1

\section{$[\ldots]$}




\section{Mezar taşı}

Basmakalıp ifadelerden olan bu şiir, ${ }^{8}$ ölen kişinin ağzından yazılmıştır. Mevta, önce kendi isteğinin yerine getirilmesini ister, bundan sonra da karşllı̆̆ında Hz. Allah'ın cenneti Fatiha okuyan kişiye vereceğini, sonucunda kendisinin kârlı çıkacağını ifade eder. Altı kırık olan bu taşın kime ait olduğu belli değildir. Fakat başlıktan bir erkek mezarı olduğu anlaşılmaktadır.
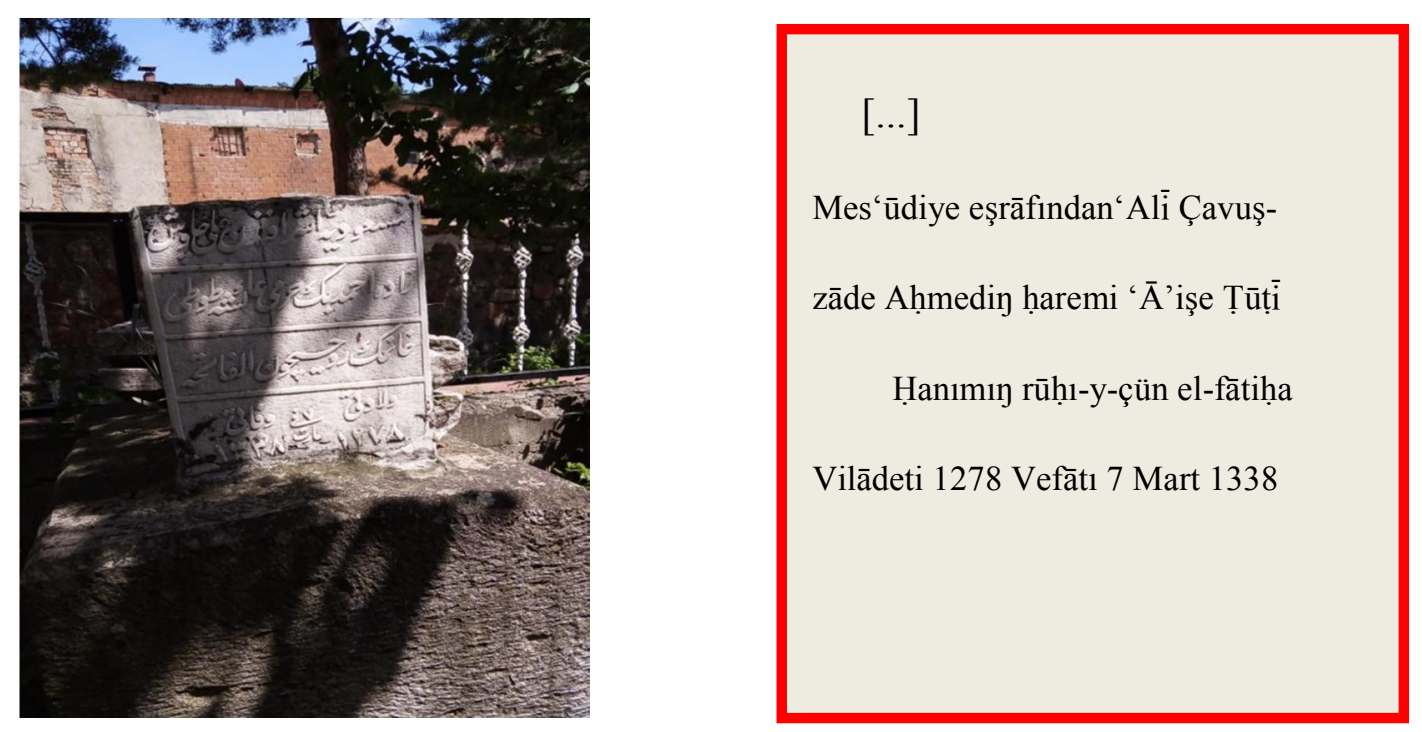

\section{Mezar taşı}

Bu mezar taşının üst tarafı kırılmış olup sadece ölen kişinin bilgilerinin olduğu bölüm bulunmaktadır. Bir hanım mezarı olup, son kısımda bütün taşlardaki gibi ölenin ruhu için bir Fatiha okunması istenmektedir. Bu taşın özelliği ise Rûmî takvimin kullanılmasıdır. 8 Recep 1340 tarihine denk gelmektedir, bu da Miladi olarak 1922 Mart'ının 7'sine tekabül eder.

\section{Mezar taşları yazılarının genel değerlendirilmesi}

Çal, makalesinde taşların yazı kısımlarını Osmanh Mezar Taşlarında Yazı ana başlığını 13 alt başlıkla incelemiştir (bk. Çal, 2015). Biz de bu başlıklardan aldığımız uygun başlıklarla incelemeye çalışacağız.

1. Başlangıç İfadesi (Serlevha): Bu kısım iki farklı şekilde görülür. Allah’ın sıfatı hüve’l baki “O bâkîdir" anlamındaki ifade beş taşta, serzeniş ifadesi $A h$, mine'l-mevt "Ah, ölümden!” ise iki taşta bulunur.

\begin{tabular}{|l|}
\hline 1. Hüve'l-Bāḳī \\
\hline 2. Hüve'l-Bākịī \\
\hline 3. Hüve'l-Bāḳī \\
\hline
\end{tabular}

8 Bu şiir, Seyyid Nizam cami haziresinde heman kelimesi ilavesiyle 51. 58. ve 68. numaralı mezar taşlarında da bulunmaktadır: (Berk, 2018: 283-284) Bakıp geçme ricâm budur Muhammed ümmeti // Ölünün diriden hemân bir fâtiha'dır minneti // Kabrimi ziyâret eden ey Rasûlün ümmeti // Bize bir fâtiha ihsân eden bulur cenneti 


\begin{tabular}{|l|}
\hline 4. Ah mine'l-mevt \\
\hline 5. Hüve'l-Bāḳīī \\
\hline 6. Hüve'l-bāḳī \\
\hline 7. Hüve'l-bāḳīi \\
\hline 8. - \\
\hline
\end{tabular}

\section{Nazım veya kitaların konusu ve teması}

Tema bakımından ölümü ele alır. Konu geride kalanlara uyarı, kendisinin canlı iken içinde bulunduğu durum ve bağışlanma için bazı isteklerdir. Buradaki mezar taşlarından beşinde nazım örneği bulunmaktadır. Mezar taşlarında görülen yaygın kalıpların bu taşlarda da kullanıldığı görülür. 5. ve 7 . taşlarda klasik mezar yazıları kullanılırken, diğer üç taştaki yazıya kaynaklarda ulaşamadım, bu taşlara özgü yazılmışs şiirler izlenimi bırakmaktadırlar.

İki taşta uyarı mahiyetinde ifadeler görülür. Birinci taşta dünyanın geçiciliği anlatılırken, üçüncü taşta ise ölenin hayattaki hâlini bilenlerin ibret almaları konusunda imalı uyarı yer alır.

Ölüm sebebi ile ilgili açık ifadeler bulunmamaktadır. İkinci taşta tarumar kelimesi ölen kişinin hayatında daha evvel olmayan karışıklığın ecelle zirveye ulaştığını göstermektedir. Üçüncü taşta sarsar ve tîr ile ifade edilen, ölenin bir dertten muzdarip olduğu ve bu dertten dolayı devrine göre orta yaş denilen bir zamanda vefat ettiği anlaşılmaktadır.

Durum bildirme ifadeleri kitaların hepsinde bulunmaktadır. Ecel gelmiş, kişiyi bulmuştur, kadere rıza gösterilmiştir. İnsan arzularının asla bitmeyeceği itiraf edilir. Dünyada murada erilemeyeceği ve ne yapılırsa yapılsın insanın isteğinin sonunun olmadığı ve dünyadan kâm alınamadığı açıça belirtilir.

Dua ruhunu teslim edenin geriye kalan tek isteğidir. İnancı gereği Allah’tan affını ve cenneti, insanlardan da Fatiha okumalarını ister. Mevta aynı zamanda kendisi için Fatiha okuyana okuması karşılığında cennete girmesi için istekte bulunur.

Temalarını tablo hâlinde şöyle gösterebiliriz:

\section{Uyarı}

Degil bir kimseye bāḳī müsāfir-ḩāne dünyā

Ḥayāt u lezzzeti bir țarfetü’l-‘ayn hayāl-efzā

1. Durum bildirme

Hamídiye Kazaāsı ḩānedān-ı 'ālī ḳadrinden

Muhammed Beg de étdi irtiḥāl-i menzil-i ‘uḳbā

1. İstek (insanlardan)

İki żamm ét çıł̣ar tārı̄h-i baḥri nāmı cevherle

Oḳu bir fātiḥa zā‘ir ḳıl üç iḩlāṣı da ibdā

\section{2. İstek (Tanrıdan)}

Yã ilāhī, gelmişim dīvānına rạ̣m ét baya

Miskinim ḳ̂l luṭfuy-1la cenneti Yā rabbenā!

Adres

İstanbul Medeniyet Üniversitesi, Eğitim Bilimleri Fakültesi, Türkçe ve Sosyal Bilimler Eğitimi Bölümü, Türkce Eğitimi ABD Cevizli Kampüsü, Kartal-İstanbul/TÜRKIYE e-posta: editor@rumelide.com
Address

İstanbul Medeniyet University, Faculty of Education Sciences,

Turkish and Social Scinces Education, Turkish Language Teaching

Education, Cevizli Campus, Kartal-İstanbul /TURKEY

e-mail: editor@rumelide.com 


\begin{tabular}{|l|}
\hline 2. Sebep bildirme \\
\hline Çün ecel geldi érişdi tārumār étdi beni \\
\hline 2. Durum bildirme \\
\hline Rāżīyım el-ḥükmü li'llāh bu imiş emr-i Ḩudā \\
\hline
\end{tabular}

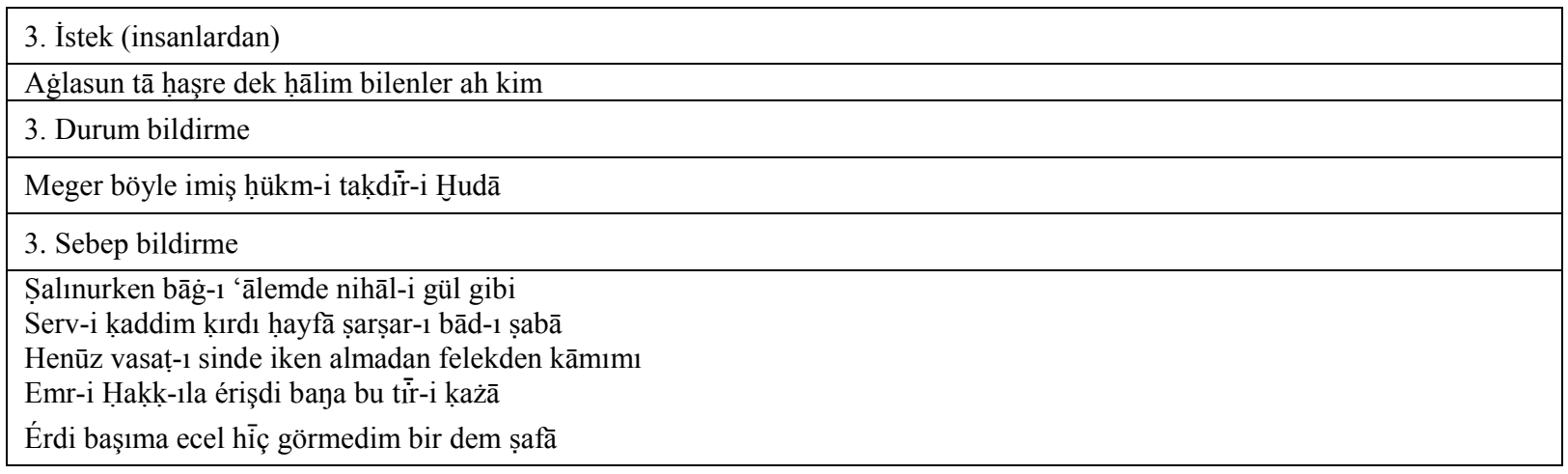

\section{Durum bildirme}

Emr étdi Hudā eyledi fermān

Érişdi ecel vérmedi amān

Murāda érmedim dünyāda hemān

5. İstek (Tanrıdan)

Cennetde vére murādım Ḥāliḳ-i cihān

\section{7. İstek (insanlardan)}

Baḳup geçme ricām budur Ey Muhammed ümmeti

Mevtānı diriden bir fătihadır minneti

Kabrimi ziyāret éden Ey Resūlüy ümmeti

Bize fãtihạa ị̣sān éden bulur cenneti .ị̣sān ḳ1

3. Memleket adı: Taşlarda kıtalardan sonra hemen kişilerin memleketi veya geldiği yer belirtilmektedir. Milas olan ilçe adı önce 1876 'da Hamidiye, 1910 yllında da Mesudiye olarak değiştirilmiştir. Memleket adı yazmayan taş, şu andaki bilgilere göre ilk belediye başkanına ait olan mezar taşlarından üçüncü taştır. ${ }^{9}$ Sivas ve Harput ismi de Mesudiye mezar taşlarında yerini almıştır.

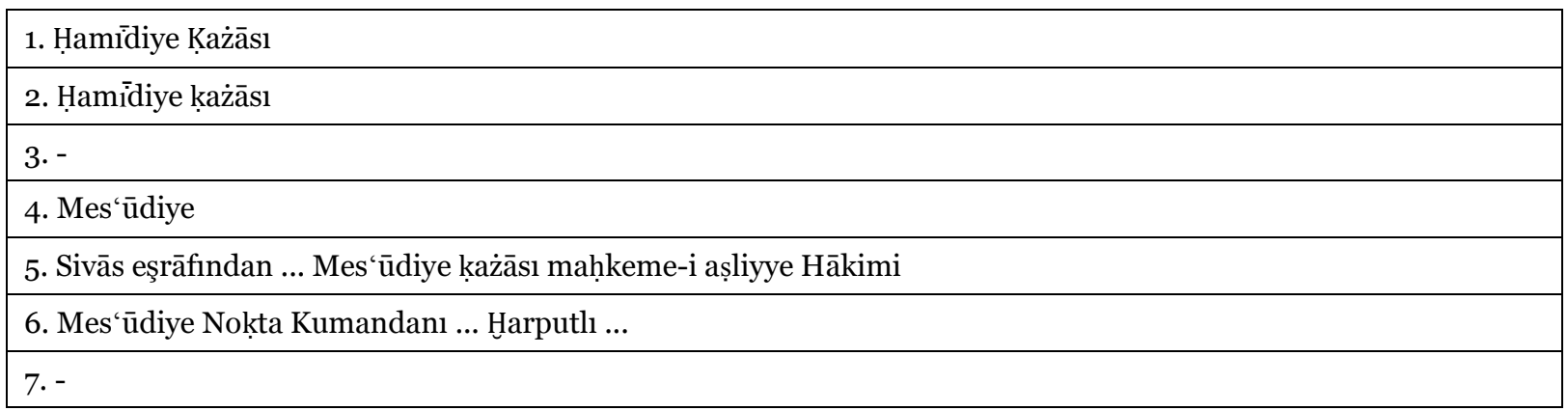

92 Kasım 1876 (Hicrî 14 Şevval 1293 / Rumî. 21 Teşrin-i evvel 1292) tarihinde Milas ismi Hamidiye olarak değiştirildi. 13 Şubat 1910 (2 Safer 1328) (31 Kânûnî-sânî 1325) yllında Hamidiye ismi de Mesudiye olarak değiştirilmiştir. (Celep, 2005: 37; 41). 1899 yılında Belediye Teşkilatı kurularak Aliçavuşoğlu Mustafa Bey ilk Belediye Başkanı olmuştur. (mesudiye.gov.tr/tarihce. ulaşım tarihi: 4.09.2020) 
8. Mes‘ūdiye

4. Sülale Adı: Aile isimlerine hânedân, zâde ve eşrâf kelimeleri ile atıf yapılmaktadır. Eşref ve Çavışzâde şeklinde geçen isimler, aynı aileyi ifade eden isimler yanında Sivas’tan Küçük-zâde sülalesi de yer alır:

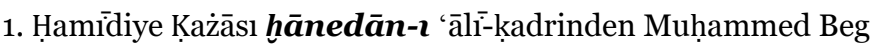

2. Ḥamīdiye ḳażāsı Eşref ḩānedānından 'Alī Çavış-zāde Aḥmed Beg

3. 'Alī Çavuş-zāde Mușțafā Beg bin Hāàcı 'Oșmān Ag̉a

4. Mes'ūdiye eşrā findan 'AlīÇavuş-zāde Muhammed Beg Ve 'Alīȩavuş-zāde Şükrī Beg

5. Mes ‘ūdiye ḳażāsı maḥkeme-i aṣliyye Hākimi Küçük-zāde Muḥammed Nūrī Beg

6. -

7. -

8. Mes'ūdiye eşrāâfindan 'Alī Çavuş-zāde Aḥmed

5. Meslek Adı: Mesudiyeli olanlar için herhangi bir meslek adı kullanılmazken dışarıdan memuriyet için gelen binbaşının ve hakimin meslekleri mezar taşına işlenmiştir:

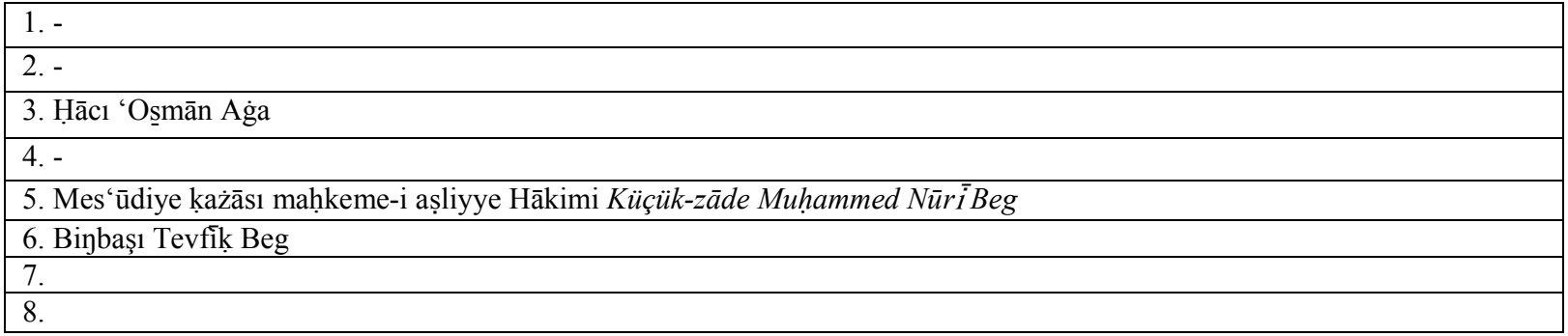

6. Erkek ve kadın adları:10 Erkeklerde 'Alī, Aḥmed, Muhammed, Şükrī, Mușțafā, Hāāi 'Oșmān Ag̉a, Muhammed Nūrí Beg (misafir), Tevfịk Beg (misafir); kadın adlarında ise Nāmıḳa, 'Ā'işe Ṭūṭi, Şefiḳa, Şehỉde Na‘ime (misafir) isimleri geçer. Sadece ölen kişinin babasının adı lakabıyla mezar taşına Hācī 'Oșmān Ağa olarak yazılmıştır.

\begin{tabular}{|l}
\hline 1. Muhammed \\
\hline 2. Aḥmed \\
\hline 3. Mușțafā - Ḥācı 'Oṣmān Ag̉a \\
\hline 4. Muḥammed - Şükrī - Şefiḳa \\
\hline 5. Muhạammed Nūrī - Nāmıḳa \\
\hline 6. Tevfiḳ - Şehìde Na'īme \\
\hline 7. - \\
\hline
\end{tabular}

8. Aḥmed - 'Ā'işe Ṭūṭi

$10 \quad$ Ordu'da Ahmet, Ali, Hasan, İbrahim, Mustafa, Süleyman (Yediylldız 1983:361-367'den aktaran; Çal, 2015: 328) Buna göre Ahmed, Ali ve Mustafa isimleri buradaki taşlarda da geçmektedir.

Adres $\mid$ Address

İstanbul Medeniyet Üniversitesi, Eğitim Bilimleri Fakültesi, Türkçe İstanbul Medeniyet University, Faculty of Education Sciences, ve Sosyal Bilimler Eğitimi Bölümü, Türkce Eğitimi ABD Cevizli Turkish and Social Scinces Education, Turkish Language Teaching Kampüsü, Kartal-İstanbul/TÜRKIYYE $\quad$ Education, Cevizli Campus, Kartal-İstanbul /TURKEY e-posta: editor@rumelide.com 1 e-mail: editor@rumelide.com 
7. İnsanlardan istek: Tanrıdan İsteği ifade eden Osmanlı mezar taşlarında görülen, dua mahiyetindeki merhum, merhume, mağfur vb. kalıplara hiç rastlanmaz. Ölen kişiler için Fatiha istenir. Hepsinde sadece Fatiha istenirken birinci taşta İhlas suresinin de okunması istenir.

\begin{tabular}{|l|}
\hline 1. Oḳu bir fātiḥa zā‘ir ḳıl üç iḩlāṣı da ibdā \\
\hline 2. rūḥı-y-çün fātiḥa \\
\hline 3. rūḥuna fātiḥa \\
\hline 4. rūḥı-y-çün fātiḥa \\
\hline 5. rūḥuna fātiḥa \\
\hline 6. rūḥı-y-çün fātiḥa \\
\hline 7. - \\
\hline 8. rūḥı-y-çün el-fātiḥa \\
\hline
\end{tabular}

8. Tarih: Tarihlerdeki ay adlarına bakılarak Rûmî veya Hicrî takvim olduğu belirlenir. Takvim çeşidi mezar taşında belirtilmemişse, ölüm ve doğumlar Rumi 1321 (Miladi 1905)'te nüfus sayımı sonrasında Rumi tarihe göre yazıldığı için, Rumi olarak değerlendirilebilir. (Özsaray, 2019: 39) Mezar taşlarında Miladi tarih de kullanılmıştır. Tarih belirtilirken tarih ve sene kelimeleri kullanılırken doğum kelimesinin karşllğ̆ olarak tevellüd ve viladet kelimeleri, ölüm için ise sadece vefat kelimesi kullanılmıştır:

\begin{tabular}{|c|c|c|c|c|}
\hline Taş & Tarih yazısı & Kullanılan & \multicolumn{2}{|c|}{ Diğer takvimlerdeki karşılığı olan tarih } \\
\hline 1 , & Sene 1 Recep 1314 & Hicri & M. 6 Aralık 1896 & R. 24 Teşrinisani 1312 \\
\hline 2. & Sene 10 Rebi"u'l-āhhir 1313 & Hicri & M. 30 Eylül 1895 & R. 18 Eylül 1311 \\
\hline 3 . & Sene Şa‘bān 1321 & Hicri & M. Ekim/Kasım 1903 & $\begin{array}{l}\text { R. Teşrinievvel/teşrinisani } \\
1319\end{array}$ \\
\hline 4. & $\begin{array}{l}\text { Tārı̄h̆-i tevellüdi sene } 1289 \\
\text { Tārı̄h̆-i vefātı sene } 1338\end{array}$ & $\begin{array}{l}\text { Hicrî } \\
\text { Rumi (?) }\end{array}$ & $\begin{array}{l}\text { M. } 1872 / 1873 \\
\text { M. } 1922\end{array}$ & $\begin{array}{l}\text { R. } 1287 / 1288 \\
\text { H. } 1340\end{array}$ \\
\hline 5 . & $\begin{array}{l}\text { Tārīh-i tevellüdi 19.. } \\
\text { Eylül Tārıh̆-i vefātı } 1928\end{array}$ & $\begin{array}{l}\text { Miladi } \\
\text { Miladi }\end{array}$ & $\begin{array}{l}\text { H. } 13 . . \\
\text { H. Rebiülevvel/Rebiülahir } \\
1347\end{array}$ & $\begin{array}{l}\text { R. } 13 . \cdot \\
\text { R. Teşrinievvel } 1344\end{array}$ \\
\hline 6. & Sene 1334 & Rumi (?) & M. 1918 & H. 1336 \\
\hline 7. & & - & - & \\
\hline 8. & $\begin{array}{l}\text { Vilādeti } 1278 \\
\text { Vefātı } 7 \text { Mart } 1338\end{array}$ & $\begin{array}{l}\text { Hicri } \\
\text { Rumi }\end{array}$ & $\begin{array}{l}\text { M. } 1861 / 1862 \\
\text { M. Mart } 1922\end{array}$ & $\begin{array}{l}\text { R. } 1277 / 1278 \\
\text { H. H.Recep/Şaban } 1340\end{array}$ \\
\hline
\end{tabular}




\section{Sonuc}

Ordu ili Mesudiye ilçesi Merkez cami haziresinde bulunan sekiz mezar taşı şekil itibarıyla dikdörtgen şekle girer. Bu mezar taşlarının dördü başlıklı, başlıkların tamamı da hamîdî feslidir. Kalan dört başlıksız taşın ikisi bitki kıvrımlı tepeli, biri üçgen tepeli, birinin ise tepesi kopuktur.

Buradaki taşlar Osmanlı mezar taşları ve yazılarının kültürünü taşımaktadır. Her mezarlığın başına gelenler bu taşların da başına gelmiş, bazıları zarar görmeden zamanımıza ulaşmış, bazıları zarar görmüştür.

Mezar taşlarında da gün yüzüne çıarılmayı bekleyen kıtalar olabilir. Bu tarih düşürülen ve benzetmelerin olduğu şiirleri taradığım hâlde ben bulamadım.

Hiçbir mezar taşında merhum ve mağfur gibi dua ve temenni cümlesi geçmez.

Mezar taşında mevtanın şiirde yer bulması dikkati çeker, mevta için ma'nen, ta'miyeli ve mu'cem olan tarih kıtası yazılmıştır.

Mezar taşında hazırlık mısraları sonraya bırakılarak anlatılmak istenen, ilk mısralarda ifade edilmiştir. Önce ölümün geldiğini ve razı olduğunu ifade edip sonra cennetin istenmesi gerekirdi.

Mezar taşında divan edebiyatında kadınlar için kullanılan mazmunlarından nihal-i gül gibi salınma ve boyun selvi gibi uzun olması erkek için kullanılmıştır.

Kadınlar için bu haziredeki taşlarda kıtalara pek yer verilmemiş̧ir. Misafir için yazılan kıta ise bütün mezar taşlarında görülen, meşhur bir kıtadır.

Taşlardaki kıtalar farklı yerlerde de mezar taşı olarak kullanılan kıtalardır. Demek ki şimdi olduğu gibi Osmanlıda da mezar taşlarında kullanılan basmakalıp kıtalar vardır.

1313 ve 1314 T1895-1897) arasındaki tarihlerde ilçe adı Hamidiye olarak geçmektedir. İlçenin adının değişmesiyle birlikte o tarihten sonraki taşlarda Hamidiye adı görülmez, yeni isim hemen yerini alır.

Osmanlı mezar taşı örnekleri olan bu hazire, üç farklı takvimin yer aldığı bir haziredir. Rebi ‘u'l-ahir 1313, Recep 1314 ve Şaban 1321 tarihleri Hicrî takvim kullanıldı ğını, sonra 1334 ve 1338 tarihleri ay adı yer almadığından Hicrî veya Rûmî olabileceğini düşündürür. Mart 1338 yazan başka bir taş ise Rûmî takvimin kullanıldığını gösterirken, tarihi en son olan taştaki Eylül 1928 kaydı artık Miladî takvime geçildiğine işaret eder.

\section{Kaynaklar}

Akün, Ö. F. (1994). Divan Edebiyatı. Türkiye Diyanet Vakfı İslâm Ansiklopedisi, (Cild 9, s. 422). Ankara: TDV Yayınları.

Berk, S. (2018). Seyyid Nizâm Mezarlı̆̆ı, Seyyid Nizâm Hz. ve Seyyid Nizâm Külliyesi. İstanbul: Zeytinburnu Belediyesi, Kültür Yayınları, Kitap No: 49.

Celep, Y. (2005). Belgelerle Ilışar Köyü Tarihi. İstanbul.

Çal, H. (2015). Türklerde Mezar - Mezar Taşları, Aile Yazıları, (Cild 8.), 295-332. Ankara: TC. Aile ve Sosyal Politikalar Bakanlığı Yayını, 295-332.

\footnotetext{
Adres $\mid$ Address

İstanbul Medeniyet Üniversitesi, Eğitim Bilimleri Fakültesi, Türkçe İstanbul Medeniyet University, Faculty of Education Sciences, ve Sosyal Bilimler Eğitimi Bölümü, Türkce Eğitimi ABD Cevizli Turkish and Social Scinces Education, Turkish Language Teaching Kampüsü, Kartal-İstanbul/TÜRKIYE Education, Cevizli Campus, Kartal-İstanbul /TURKEY e-posta: editor@rumelide.com 1 e-mail: editor@rumelide.com
} 
Çoruhlu, Y , Çakır, Ö . (2011). Ordu'nun Mesudiye İlçesi / Kale Köyü'nden Bir Türkmen Kalesi, Mezar Taşları ve Üç Mezar Anıtı. Tarih Dergisi, o (36), 81-136. https://dergipark.org.tr/tr/pub/iutarih/issue/9608/119991

Dilçin, D. (1983). Örneklerle Türk Şiir Bilgisi. Ankara: Türk Dil Kurumu Yayınları.

Karabey T. (2015). Türk Edebiyatında Tarih Düşürme. Ankara: Atatürk Kültür Merkezi Başkanlığı.

Özsaray, M. (2019). Hazine-i Evrak. Arşiv ve Tarih Araştırmaları Dergisi, (Cilt 1, Sayı 1), 28 - 41.

Sarıkaya, B. (2020). Türk Edebiyatında Tarih Düşürme. Kesit Akademi Dergisi 6(23), 352-362. http://dx.doi.org/10.29228/kesit.43868

Yanık, N - Kındığılı, M . (2013). Narlı Köyü Camii ve Haziresi . Güzel Sanatlar Enstitüsü Dergisi , o (28), 75-103 . https://dergipark.org.tr/tr/pub/ataunigsed/issue/2581/33223 